\title{
Relationship between identity and attitude toward death in Japanese senior citizens
}

\author{
Satomi Nakagi ${ }^{12}$ and Toshiko Tada \\ 'Major in Health Science, Graduate School of Health Sciences, the University of Tokushima, Tokushima, \\ Japan, ${ }^{2}$ Faculty of Nursing, Shikoku University, Tokushima, Japan, ${ }^{3}$ Major in Nursing, Institute of \\ Health Biosciences, the University of Tokushima, Tokushima, Japan
}

\begin{abstract}
This study aimed to clarify the relationship between identity development stages and attitudes towards death among Japanese senior citizens. The subjects were recruited from among approximately 500 students attending educational courses for senior citizens in Prefecture A. We collected the data by using the questionnaire and interview. The contents of questionnaire were Erikson Psychosocial Stage Inventory (EPSI) and Death Attitude Profile-Revised (DAP-R). In the interview, we represented the four developmental stages, and asked the questions from birth to the present. The collection rate was $85.4 \%$ (427 subjects). And 10 subjects participated in the interview. In relation to correlations between the EPSI sub-factors and the DAP-R subscales, there were moderately strong, negative correlations between "Integrity" and "Fear of death" and between "Integrity" and "Avoidance of death". In relation to the subjects' reflections on their lives, the following four categories were extracted : [Trust relationships with others], [Self-confidence regarding my own efforts], [Wanting to contribute to society], and [Let things be as they are]. These results suggested that the accomplishment of "Integrity", which is the developmental task in the maturity stage, leads to the attitude of accepting one's whole life. Further, we have clarified that "Integrity" promotes the acceptance of death. J. Med. Invest. 61 : 103-117, February, 2014
\end{abstract}

Keywords : senior citizens, identity, attitude toward death

\section{INTRODUCTION}

The population of senior citizens aged 65 or over in Japan reached 30.79 million in October 2012, with a population aging rate of $24.1 \%$. This rate has been increasing since Japan became a so-called superaged society in 2007. In particular, the population of persons aged 75 years or older is expected to exceed the population of persons between 65 and 74

Received for publication December 2, 2013 ; accepted December $18,2013$.

Address correspondence and reprint requests to Satomi Nakagi, Faculty of Nursing, Shikoku University, 123-1 Ebisuno, Furukawa, Ojin-cho, Tokushima-shi, Tokushima 771-1192, Japan and Fax: +81-88-665-8037. years old in 2017, and to continue to rise (1). Accordingly, Japan is expected to be a society with a high death rate. The term "high death rate" has a negative connotation, but considering that many senior citizens die natural deaths, this situation suggests a high quality of life and indicates that senior citizens accomplish the developmental task of what Erikson $(2,3)$ called "Ego-Integrity". According to Erikson $(2,3)$, maturity is the stage for embarking on the psychosocial risk of "Ego-Integrity against Despair" and to reflect on what one has accomplished in one's lifetime. One of the current social issues is how senior citizens can accomplish their final developmental task of "Ego-Integrity" and face their last years in a healthy manner. We believe that 
public health personnel should play a supporting role for senior citizens in helping them to complete their lives in a positive way.

During the maturity stage, people feel their physical strength weakening and frequently witness the deaths of persons close to them. Consequently, they have no choice but to face their own death as it approaches.

The way senior citizens face their own death is an important factor in how they complete their lives. Previous studies reported that the attitude of senior citizens toward their own death is subject to the influence of factors such as whether they have a family member living with them and their hobbies and bereavement experiences (4-8). Kawai and Yanagita (9) stated the importance of thorough reflection on one's own life based on the expectation of one's own death. As problems in terminal care have attracted attention in recent years, it has become inevitable to take death into account when considering the lives of modern people (9). Further, Kouno (10) suggested that becoming sick, especially being in a terminal state, is the best opportunity for selffulfillment. According to Newman and Newman (11), overcoming the psychosocial risk of "EgoIntegrity against Despair" in the maturity stage (2, 3) requires the accomplishment of the following four developmental tasks : "Responding to physical changes due to aging", as exemplified by slowed physical movements and weakened sensory receptors ; "Redirecting one's life to a new role", which means directing one's energy towards acquisition of a new role and activities ; "Accepting one's own life", meaning one's evaluation and acceptance of one's own life so far ; and "Development of the perspective on death", meaning that one accepts one's death as an extension of one's life. Furthermore, Levinson (12) pointed out that the theme of the maturity stage is to find significance and value in one's own life even if it has not been perfect. Accomplishing this task is considered to enable people to accept their death without despair or pain.

From these studies, the time for senior citizens to consider their own death without turning away from it is a valuable time for them to achieve personal maturity and complete their lives.

Therefore, the present study focuses on senior citizens living in a community who were able answer a questionnaire and participate in interviews as the study subjects. This study aimed to clarify the relationship between identity development stages and attitudes towards death among senior citizens.
In particular, the purpose of our interviews was to grasp, from the reflections and narratives of senior citizens on their lives, the individuality and universality in their understanding and acceptance of their lives in the ego-integrity process. This enabled a detailed analysis of the relevance to identity development of senior citizens' attitudes towards their own death from their perspective. We anticipate that the results of this research will indicate that senior citizens' acceptance of their "eventual death", which is inevitable regardless of their health status, not only assists their attitude toward death but also leads to improvements in their present lifestyles. In this study, we conducted to develop the intervention method for supporting the senior citizens in their acceptance of death.

\section{MATERIALS AND METHODS}

\section{Definition of "Ego-integrity"}

"Ego-integrity" in this research employed the definition in the theory of personality developed by Erikson $(2,3)$, that is, "the attitude of accepting one's whole life, including positive and negative memories, and the process of seeking significance for one's own life and finding value in oneself'.

\section{Ethical considerations}

We explained the aim and significance of the research to the subjects, informing them orally and in writing that their participation and cooperation in the questionnaire survey and interviews were voluntary, and that withdrawal in the course of the research would create no disadvantage to them. Only those subjects whose consent was obtained participated in the research. The questionnaire sheet also stated the purpose of the research, our strict observance of the subjects' freedom in answering the questions, our assurance of their anonymity, and our assurance that their data would not be used for purposes other than this research. The questionnaire sheet further stated the possibility that the subjects might feel uncomfortable with some questions about their mental state. After providing sufficient explanations, we asked only those subjects who consented to the research to participate in the questionnaire survey and interviews.

This study was approved by the Ethics Committee of Tokushima University Hospital (Approval No. 1468). 


\section{Survey methods}

1. Questionnaire survey

1) Subjects

The study subjects were recruited from among approximately 500 students attending educational courses and advanced-level educational courses for the elderly in Prefecture A. These courses are usually called "silver daigaku" in Japanese.

2) Research period and data collection methods

Between July and September 2012, we distributed the anonymous questionnaire sheets at the "silver daigaku" site and requested the subjects to voluntarily complete and place the completed questionnaire sheet into the designated collection box.

3) Research content

(1) Face sheet

To learn basic attributes of the subjects, we asked questions about their age, sex, subjective view on their health state and chronic diseases, and the presence/absence of any family member(s) living with them.

\section{(2) Erikson Psychosocial Stage Inventory (EPSI) $(13,14)$}

This is a scale corresponding to the model of identity development stages formulated by Erikson. Its purpose is to measure and evaluate the level of an individual's accomplishment of psychosocial developmental tasks and to comprehensively grasp the identity of that individual in its entirety. Nakanishi et al. (13) developed the Japanese version of the EPSI through multiple revisions and verified its reliability and adequacy $(13,14)$. The accomplishment level of developmental tasks was measured and evaluated with the following eight subscales : trust, autonomy, initiative, industry, identity, intimacy, generativity and integrity. Each subscale was composed of seven items ; therefore, the total number of item was 56 . Each item was answered by selecting one of five levels, from 1, "Not applicable at all" to 5, "Very applicable".

Using the total score, it is possible to evaluate a person's identity accomplishment level. Each of the subscales can be used as an indicator of an individual's accomplishment of each psychosocial developmental task.

(3) Death Attitude Profile-Revised (DAP-R) $(15,16)$

The DAP-R is a multidimensional scale consisting of the following five factors with regard to the attitude toward death : fear of death, avoidance of death, neutral acceptance, escape acceptance, and approach acceptance $(15,16)$. In relation to the
Japanese version of the scale created by Kumabe (16), high reliability and validity of the above factors, except for neutral acceptance, have been confirmed (16). Accordingly, we excluded the factor of neutral acceptance due to its low reliability and included all four of the remaining factors. From these changes, the total number of items became 22 . For these 22 items, we asked the subjects to give their answers by selecting one of five levels, from 1, "Not applicable at all" to 5, "Very applicable".

4) Analytical methods

The statistical analysis below was performed using SPSS Ver. 20J (SPSS Japan Inc., Tokyo, Japan). We calculated the Cronbach's coefficient alphas of the DAP-R sub-factors and the EPSI sub-factors and tested their reliability. Further, we tested differences between the EPSI sub-factors and DAP-R sub-factors according to two age groups (subjects aged 60 to 74 years old and those aged 75 or over), according to sex, and according to two groups of subjects based on subjective views on health (subjects with positive views and those with negative views). We then tested differences in the DAP-R sub-factors between two groups of subjects with high and low scores of EPSI "Integrity". For these tests, a non-parametric Mann-Whitney U test was used. For correlations between the EPSI factors and the DAP-R factors, Spearman's rank correlation coefficients were calculated. Using variables indicating significant relationships in the tests above as independent variables, and the DAP-R factors as dependent variables, we conducted a multiple regression analysis. Among the EPSI factors, we conducted a multiple regression analysis on those factors extracted as significant variables together with their sub-questions. All p-values were two-sided, and the level of significance was set below $5 \%$.

\section{Interview survey}

1) Subjects

When the questionnaire survey was conducted, the request for interview participation was written on the last page of the questionnaire sheet. The sheet also stated that consent to or refusal of interview participation would cause no disadvantage. The subjects were asked to enter their name and contact information if they agreed to participate in the interviews.

2) Interview period

The interview period was from April to August 2013. 


\section{3) Interview contents}

With reference to the Life Review and Experience Form (LREF) developed by Haight et al. (17), its Japanese version prepared by Nomura (18), and other previous studies (19-21), we created an interview guide (Table 1 ). We conducted semi-structured interviews, which encompassed the four stages of childhood, adolescence, adulthood, and maturity. We selected question items, each of which represented the four developmental stages, and asked the questions from birth to the present. Upon obtaining the consent of the subjects, we recorded the interviews with an IC recorder.

4) Analytical method

(1) Based on the recorded content of the interviews, we created a verbatim record in accordance with the interview guide.

(2) With regard to each of the developmental stages, we extracted words expressing the subjects' ways of understanding and accepting their own lives, ways of accepting their death, and ways of coping with difficulties in life, and words spoken of their eventual death, together with the contexts in which such words were spoken.

(3) The aforementioned details were categorized and sub-categorized.

(4) Two authors read the recorded content of the interviews individually, and categorized again and again until the match.

\section{RESULTS}

\section{Questionnaire survey}

We received responses from 427 subjects (collection rate : $85.4 \%$ ), and excluded 63 subjects for whom there were many missing values. Consequently, responses from 364 subjects were considered valid ; the valid collection rate was $85.2 \%$. The subjects were 153 men and 211 women, with an average age of 67 years, standard deviation of 4.8 years, and age range of 60 to 87 years. Table 2 lists the basic attributes of the subjects.

Table 3 shows the alpha coefficients of the EPSI sub-factors and the DAP-R sub-factors. The alpha coefficient of "Generativity," one of the eight EPSI sub-factors, was 0.59 . The alpha coefficients of the other seven EPSI sub-factors were within the range of 0.62 to 0.73 . The alpha coefficients of the DAP-R sub-factors were within the range of 0.81 to 0.90 .

Table 1. Interview Guide to Investigate Senior Citizens' Identity Development Stage and Attitude Toward Death

\begin{tabular}{|c|c|}
\hline Developmental Stage & Contents of Questions \\
\hline Childhood & $\begin{array}{l}\text { The first thing in your life that you can still remember } \\
\text { School life, playing with your friends, helping your family } \\
\text { Relationships with your family members, memories with your family } \\
\text { Things you enjoyed and did not enjoy during this period }\end{array}$ \\
\hline Adolescence & $\begin{array}{l}\text { Scenes from your school life, your relationships with your friends } \\
\text { Things that you put your heart into } \\
\text { Things you enjoyed and did not enjoy during this period } \\
\text { The thing from this period that you remember most }\end{array}$ \\
\hline Adulthood & $\begin{array}{l}\text { Your work life and feelings toward work since you started working } \\
\text { Your friendship during this period } \\
\text { Marriage, childbirth } \\
\text { Hardship and joy you experienced in raising your child } \\
\text { The self-reliance and marriage of your child } \\
\text { Your hobby }\end{array}$ \\
\hline Maturity & $\begin{array}{l}\text { Your memories after retirement } \\
\text { Your relationships with and feelings for your grandchild } \\
\text { Your ways to spend leisure time } \\
\text { Your current friendship } \\
\text { Your current life, and the things you want to enjoy now and in the future }\end{array}$ \\
\hline Summary & $\begin{array}{l}\text { The most memorable thing that happened in your life so far } \\
\text { The thing you enjoyed most in your life so far } \\
\text { The most painful event that happened to you in your life so far } \\
\text { When you overview your life, what kind of life is yours? } \\
\text { If you were to live your life again, what would you want to change? } \\
\text { When you experienced difficulty, how did you cope with/overcome it? } \\
\text { Compare young people today with yourself when you were young } \\
\text { Your message to young people }\end{array}$ \\
\hline Last moment of life & $\begin{array}{l}\text { What do you think of "your last moment" which will eventually come? } \\
\text { What kind of last moment do you want to have? }\end{array}$ \\
\hline
\end{tabular}


Table 2. Basic attributes of the questionnaire survey subjects

\begin{tabular}{|c|c|c|c|}
\hline Basic attributes & Total & Level (No. of Subjects) & Rate (\%) \\
\hline \multirow[t]{2}{*}{ Sex } & Men & 153 & 42 \\
\hline & Women & 211 & 58 \\
\hline \multirow[t]{6}{*}{ Age group } & $60 \sim 64$ & 123 & 33 \\
\hline & $65 \sim 69$ & 143 & 39 \\
\hline & $70 \sim 74$ & 69 & 19 \\
\hline & $75 \sim 79$ & 21 & 6 \\
\hline & $80 \sim 84$ & 6 & 2 \\
\hline & $85 \sim$ & 2 & 1 \\
\hline \multirow{2}{*}{$\begin{array}{l}\text { Presence/absence of a person } \\
\text { living together }\end{array}$} & Living together & 293 & 81 \\
\hline & Living alone & 71 & 19 \\
\hline \multirow[t]{3}{*}{ Friend } & None & 14 & 4 \\
\hline & Some & 230 & 63 \\
\hline & Many & 120 & 33 \\
\hline \multirow[t]{4}{*}{ Subjective sense of health } & $\mathrm{Bad}$ & 6 & 2 \\
\hline & Bad to some extent & 67 & 18 \\
\hline & Good to some extent & 178 & 48 \\
\hline & Good & 116 & 32 \\
\hline \multirow{2}{*}{$\begin{array}{l}\text { Presence/absence of chronic } \\
\text { diseases }\end{array}$} & I have & 213 & 58 \\
\hline & I do not have & 151 & 42 \\
\hline \multirow[t]{2}{*}{ Nursing-care insurance } & I am using & 6 & 2 \\
\hline & I am not using & 358 & 98 \\
\hline \multirow[t]{3}{*}{ Driving a car } & I drive & 328 & 90 \\
\hline & I do not drive & 31 & 9 \\
\hline & I do not drive at present & 5 & 1 \\
\hline \multirow[t]{3}{*}{ Work } & I am working & 92 & 25 \\
\hline & I am not working & 181 & 50 \\
\hline & I am not working at present & 91 & 25 \\
\hline
\end{tabular}

The rates $(\%)$ are against $\mathrm{n}=364$

Table 3. Internal consistency of each factor

$(\mathrm{n}=364)$

\begin{tabular}{cccc}
\hline Scale & Factor name & Item No. & Alpha coefficients \\
\hline & Trust & 7 & 0.64 \\
& Autonomy & 7 & 0.71 \\
& Initiative & 7 & 0.71 \\
& Industry & 7 & 0.72 \\
& Identity & 7 & 0.73 \\
& Intimacy & 7 & 0.62 \\
& Generativity & 7 & 0.59 \\
\hline Integrity & 7 & 0.63 \\
\hline DAP-R & Approach acceptance & 7 & 0.86 \\
& Fear of death & 8 & 0.90 \\
& Avoidance of death & 5 & 0.84 \\
\hline
\end{tabular}


Regarding sexual differences, the female subjects showed significantly higher scores in "Trust", "Autonomy", and "Generativity" than the male subjects (Table 4). According to age, the scores of subjects aged 75 years or older were significantly higher in the EPSI factors of "Industry" and "Generativity" than the scores of subjects aged between 60 and 74 years (Table 5). In comparing the scores for "Integrity", we divided the scores into two groups of high and low integrity at the median of 24 . The high integrity group scored significantly higher on the EPSI subscales and significantly lower on the DAP-R subscales of "Fear of death", "Avoidance of death", and "Escape acceptance" compared with the low integrity group (Table 6). In relation to correlations between the EPSI sub-factors and the DAP-R subscales, there were moderately negative correlations between "Integrity" and "Fear of death" and

Table 4. Comparison of EPSI and DAP-R according to sex

$(\mathrm{n}=364)$

\begin{tabular}{|c|c|c|c|c|c|c|c|c|c|c|c|c|c|}
\hline & \multirow[b]{2}{*}{$n$} & \multicolumn{8}{|c|}{ EPSI } & \multicolumn{4}{|c|}{ DAP-R } \\
\hline & & Trust & Autonomy & Initiative & Industry & Identity & Intimacy & Generativity & Integrity & $\begin{array}{l}\text { Approach } \\
\text { acceptance }\end{array}$ & $\begin{array}{l}\text { Fear of } \\
\text { death }\end{array}$ & $\begin{array}{c}\text { Avoidance } \\
\text { of death }\end{array}$ & $\begin{array}{c}\text { Escape } \\
\text { acceptance }\end{array}$ \\
\hline Men & 153 & 160.65 & 167.45 & 184.51 & 179.21 & 175.71 & 162.67 & 190.76 & 174.56 & 176.32 & 181.98 & 189.67 & 184.38 \\
\hline Women & 211 & 198.34 & 193.41 & 181.05 & 184.89 & 187.42 & 196.88 & 176.51 & 188.26 & 186.98 & 182.88 & 177.30 & 181.14 \\
\hline$U$ value & & $12799.00^{* *}$ & $13839.00^{*}$ & 15834.50 & 15638.00 & 15103.00 & $13107.50^{* *}$ & 14877.50 & 14926.00 & 15196.50 & 16062.00 & 15045.00 & 15854.50 \\
\hline $\begin{array}{c}p \text { value } \\
\text { (two-sided) }\end{array}$ & & 0.00 & 0.02 & 0.76 & 0.61 & 0.29 & 0.00 & 0.20 & 0.22 & 0.34 & 0.94 & 0.27 & 0.77 \\
\hline
\end{tabular}

Mann-Whitney $U$ Test $* p<0.05 * * p<0.01$

EPSI : Erikson Psychosocial Stage Inventory

DAP-R : Death Attitude Profile-Revised

Table 5. Comparison of EPSI and DAP-R according to age

$(n=364)$

\begin{tabular}{|c|c|c|c|c|c|c|c|c|c|c|c|c|c|}
\hline & \multirow[b]{2}{*}{$n$} & \multicolumn{8}{|c|}{ EPSI } & \multicolumn{4}{|c|}{ DAP-R } \\
\hline & & Trust & Autonomy & Initiative & Industry & Identity & Intimacy & Generativity & Integrity & $\begin{array}{l}\text { Approach } \\
\text { acceptance }\end{array}$ & $\begin{array}{c}\text { Fear of } \\
\text { death }\end{array}$ & $\begin{array}{l}\text { Avoidance } \\
\text { of death }\end{array}$ & $\begin{array}{c}\text { Escape } \\
\text { acceptance }\end{array}$ \\
\hline $\begin{array}{l}\text { Aged between } \\
60 \text { and } 74\end{array}$ & 335 & 179.79 & 179.54 & 179.85 & 178.91 & 179.12 & 182.32 & 178.18 & 179.35 & 179.69 & 183.01 & 181.55 & 183.38 \\
\hline $\begin{array}{l}75 \text { years old } \\
\text { or older }\end{array}$ & 29 & 213.76 & 216.74 & 213.09 & 223.95 & 221.53 & 184.53 & 232.38 & 218.91 & 215.02 & 176.59 & 193.48 & 172.31 \\
\hline$U$ value & & 3951.00 & 3864.50 & 3970.50 & $3655.50 *$ & 3725.50 & 4798.50 & $3411.00 * *$ & 3801.50 & 3914.50 & 4686.00 & 4539.00 & 4562.00 \\
\hline $\begin{array}{c}p \text { value } \\
\text { (two-sided) }\end{array}$ & & .09 & .07 & .10 & .03 & .04 & .91 & .00 & .05 & .08 & .75 & .56 & .58 \\
\hline
\end{tabular}

Mann-Whitney $U$ Test $* p<0.05 * * p<0.01$

EPSI : Erikson Psychosocial Stage Inventory

DAP-R: Death Attitude Profile-Revised

Table 6. Comparison of EPSI and DAP-R according to integrity

$(n=364)$

\begin{tabular}{|c|c|c|c|c|c|c|c|c|c|c|c|c|}
\hline & \multirow[b]{2}{*}{$n$} & \multicolumn{7}{|c|}{ EPSI } & \multicolumn{4}{|c|}{ DAP-R } \\
\hline & & Trust & Autonomy & Initiative & Industry & Identity & Intimacy & Generativity & $\begin{array}{l}\text { Approach } \\
\text { acceptance }\end{array}$ & $\begin{array}{c}\text { Fear of } \\
\text { death }\end{array}$ & $\begin{array}{c}\text { Avoidance } \\
\text { of death }\end{array}$ & $\begin{array}{c}\text { Escape } \\
\text { acceptance }\end{array}$ \\
\hline $\begin{array}{l}\text { Low integrity } \\
(24 \leqq)\end{array}$ & 200 & 127.73 & 132.33 & 135.48 & 136.94 & 124.98 & 146.09 & 142.63 & 188.19 & 222.08 & 212.28 & 208.54 \\
\hline $\begin{array}{l}\text { High integrity } \\
\quad(25 \geqq)\end{array}$ & 164 & 249.30 & 243.69 & 239.84 & 238.06 & 252.65 & 226.91 & 231.12 & 175.57 & 134.23 & 146.19 & 150.74 \\
\hline$U$ value & & $5445.00 * *$ & $6365.00 * *$ & $6996.00 * *$ & $7287.50 * *$ & $4895.50 * *$ & 9117.50 ** & $8426.50 * *$ & 15263.00 & $8484.00 * *$ & $10445.00 * *$ & $11191.50 * *$ \\
\hline $\begin{array}{c}p \text { value } \\
\text { (two-sided) }\end{array}$ & & 0.00 & 0.00 & 0.00 & 0.00 & 0.00 & 0.00 & 0.00 & 0.25 & 0.00 & 0.00 & 0.00 \\
\hline
\end{tabular}

Mann-Whitney $U$ Test $* p<0.05 * * p<0.01$

EPSI : Erikson Psychosocial Stage Inventory

DAP-R: Death Attitude Profile-Revised 
between "Integrity" and "Avoidance of death". There was a weak, negative correlation between "Integrity" and "Escape acceptance" (Table 7). Regarding effects of the EPSI sub-factors on the DAP-R sub-factors, the adjusted $\mathrm{R}^{2}$ was 0.03 in "Approach acceptance". On "Fear of death", "Integrity" $(\beta=-0.54)$ indicated negative effects. On "Avoidance of death", "Integrity" ( $\beta=-0.37)$ had a negative effect. On "Escape acceptance", "Initiative" $(\beta=-0.23)$ and "Integrity" $(\beta=-0.18)$ indicated negative effects. "Integrity" indicated a negative effect on the DAP-R sub-factors except "Approach acceptance" (Table 8). Regarding effects of the sub-items of "Integrity"

Table 7. Correlation coefficients between factors $\quad(n=364)$

\begin{tabular}{|c|c|c|c|c|c|}
\hline & \multicolumn{4}{|c|}{ DAP-R } \\
\hline & & $\begin{array}{c}\text { Approach } \\
\text { acceptance }\end{array}$ & $\begin{array}{l}\text { Fear of } \\
\text { death }\end{array}$ & $\begin{array}{l}\text { Avoidance } \\
\text { of death }\end{array}$ & $\begin{array}{c}\text { Escape } \\
\text { acceptance }\end{array}$ \\
\hline \multirow{8}{*}{ EPSI } & Trust & -.01 & $-.28 * *$ & $-.20 * *$ & $-.19 * *$ \\
\hline & Autonomy & -.07 & $-.25^{* *}$ & $-.22 * *$ & $-.20 * *$ \\
\hline & Initiative & $-.11 * *$ & $-.26^{* *}$ & $-.21 * *$ & $-.24 * *$ \\
\hline & Industry & -.03 & $-.15^{* *}$ & $-.14 * *$ & $-.19 * *$ \\
\hline & Identity & -.07 & $-.23 * *$ & $-.20 * *$ & $-.21 * *$ \\
\hline & Intimacy & .00 & $-.14 * *$ & $-.11 * *$ & $-.14 * *$ \\
\hline & Generativity & .03 & $-.14 * *$ & $-.10 *$ & $-.15^{* *}$ \\
\hline & Integrity & $-.08^{*}$ & $-.39 * *$ & $-.29 * *$ & $-.22 * *$ \\
\hline
\end{tabular}

Spearman's rank correlation coefficient $* p<0.05 * * p<0.01$ EPSI : Erikson Psychosocial Stage Inventory

DAP-R : Death Attitude Profile-Revised

Table 8. Results of multiple regression analysis with EPSI subscales as independent variables and DAP-R as dependent variable

$(\mathrm{n}=364)$

\begin{tabular}{ccccc}
\hline DAP-R & $\begin{array}{c}\text { Approach } \\
\text { acceptance }\end{array}$ & $\begin{array}{c}\text { Fear of } \\
\text { death }\end{array}$ & $\begin{array}{c}\text { Avoidance } \\
\text { of death }\end{array}$ & $\begin{array}{c}\text { Escape } \\
\text { acceptance }\end{array}$ \\
\cline { 2 - 5 } EPSI & $\beta$ & $\beta$ & $\beta$ & $\beta$ \\
Trust & - & - & - & - \\
Autonomy & - & - & $-.19^{* *}$ & - \\
Initiative & $-.24^{* *}$ & - & - & $-.23^{* *}$ \\
Industry & - & - & - & - \\
Identity & - & - & - & - \\
Intimacy & - & - & - & - \\
Generativity & $.20^{* *}$ & - & $.16^{* *}$ & - \\
Integrity & - & $-.54^{* *}$ & $-.37^{* *}$ & $-.18^{* *}$ \\
\hline R & .04 & .29 & .20 & .14 \\
Adjusted $\mathrm{R}^{2}$ & .03 & .29 & .19 & .13 \\
$\mathrm{~F}$ & $7.00^{* *}$ & $150.23^{* *}$ & $29.18^{* *}$ & $28.96^{* *}$ \\
\hline
\end{tabular}

Stepwise method, the $\beta$ values are the values in the last step $* p<0.05 * * p<0.01$

EPSI : Erikson Psychosocial Stage Inventory

DAP-R : Death Attitude Profile-Revised of the EPSI on the DAP-R sub-factors, the partial regression coefficients of the four question items under "Integrity" against "Fear of death" were significant ( $\beta=-0.14$ to -0.48$)$ (Table 9).

Table 9. Results of multiple regression analysis with sub-items of EPSI integrity as independent variables and DAP-R as dependent variables $(n=364)$

\begin{tabular}{cccccc}
\hline \multirow{2}{*}{ DAP-R } & $\begin{array}{c}\text { Approach } \\
\text { acceptance }\end{array}$ & $\begin{array}{c}\text { Fear of } \\
\text { death }\end{array}$ & $\begin{array}{c}\text { Avoidance } \\
\text { of death }\end{array}$ & $\begin{array}{c}\text { Escape } \\
\text { acceptance }\end{array}$ \\
\cline { 2 - 6 } & $8^{*}$ & $-.15^{* *}$ & $-.48^{* *}$ & $-.32^{* *}$ & $-.14^{*}$ \\
& 16 & - & - & - & - \\
& $24^{*}$ & - & - & - & $-.16^{* *}$ \\
EPSI & 32 & - & - & - & - \\
Integrity & 40 & - & $-.18^{* *}$ & $-.22^{* *}$ & - \\
& $48^{*}$ & $-.11^{*}$ & $-.14^{* *}$ & $-.15^{* *}$ & $-.20^{* *}$ \\
& $56^{*}$ & - & $-.16^{* *}$ & - & - \\
\hline R & & .04 & .45 & .25 & .13 \\
Adjusted $\mathrm{R}^{2}$ & & .04 & .44 & .25 & .12 \\
F & & $8.28^{* *}$ & $72.93^{* *}$ & $40.71^{* *}$ & $18.17^{* *}$ \\
\hline
\end{tabular}

Stepwise method, the $\beta$ values are the values in the last step, the integrity numbers are the subscale question numbers $* p<0.05 \quad * * p<0.01$

Contents of items (Items with * are inverted items)

$8^{*}$ : I feel anxious when I think that I am going to die

$16:$ My life so far is invaluable

$24 *$ : I have nothing to live for

32 : I have been living a life without any regret

40 : I can accept my own death

$48^{*}$ : I think there are other ways I can live my life $56^{*}:$ My life is full of mistakes

\section{Interview survey}

Thirty subjects were willing to participate in our interviews. We chose 10 subjects as the interview subjects after excluding those who had inconveniences such as being unwell or having difficult family circumstances. The 10 interview subjects consisted of 6 men and 4 women, with an average age of 72 years, standard deviation of 6.4 years, and age range of 60 to 87 years. The basic attributes of the subjects are shown in Table 10.

The subjects' understanding and acceptance of life in each of the developmental stages, their acceptance of and coping with difficulties in life, and their acceptance of their own death were codified and categorized (Tables 11 to 14, Figure 1). Hereafter, such categories are enclosed in [ ], subcategories in \langle\rangle and codes and narratives in " ".

The common categories for all the stages from childhood to maturity were [Trust relationships with 
Table 10. Overview of the interview subjects

\begin{tabular}{cccccccc}
\hline $\begin{array}{c}\text { Interview } \\
\text { subjects }\end{array}$ & Sex & Age & Person living together & Health condition & Chronic disease & Work & $\begin{array}{c}\text { EPSI } \\
\text { total scores }\end{array}$ \\
\hline A & Male & 69 & Wife & Good & None & Yes & 228 \\
B & Female & 77 & Husband & Good & None & No & 215 \\
C & Female & 72 & Husband, Son and his wife, Daughter & Good & None & Yes & 216 \\
D & Male & 72 & Wife & Good to some extent & Heart disease & No & 212 \\
E & Male & 74 & Wife, Son and his wife, Wife's brother, & Good to some extent & None & No & 221 \\
F & Female & 66 & Grandchildren & Good to some extent & None & No & 123 \\
G & Male & 71 & Son & Good to some extent & Heart disease & No & 203 \\
H & Female & 75 & Alone & Good to some extent & Diabetes & Yes & 224 \\
I & Male & 66 & Wife and son & Bad to some extent & Kidney disease, Diabetes & Yes & 208 \\
J & Male & 87 & Wife & Good to some extent & Heart disease & No & 180 \\
\hline
\end{tabular}

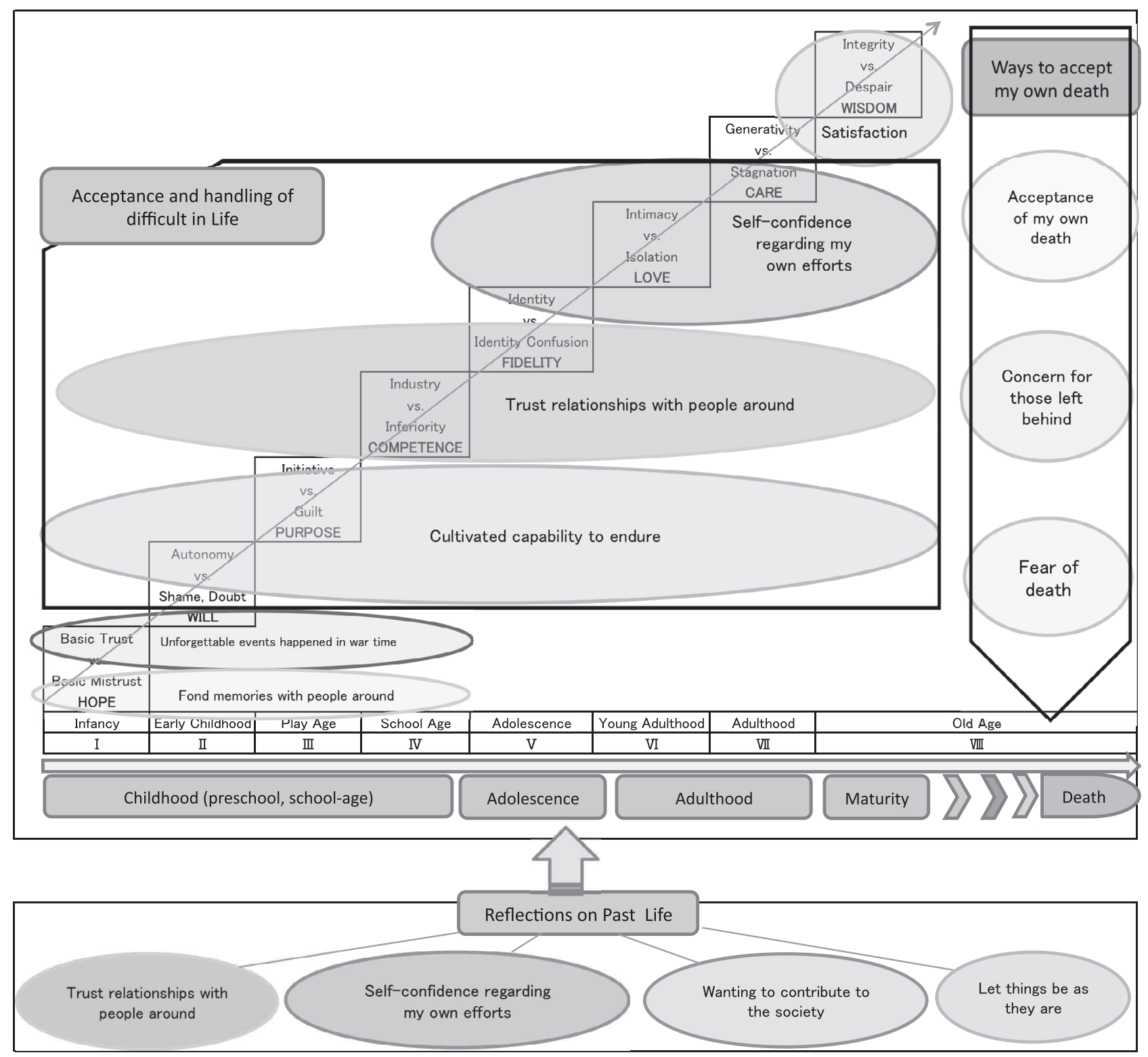

Figure 1 Result of semi-structured interviews

Referred a part of the epigenesis chart : Psychosocial development stages of life by Erikson $(2,3,22,23)$ 
others] and [Cultivated capability to endure]. The categories which were extracted only from the stage of childhood were [Fond memories with others] and [Unforgettable events that happened during wartime]. The category common to the stages from adolescence to maturity was [Self-confidence regarding my own efforts]. The category newly extracted at the stage of maturity was [Satisfaction]. The category [Trust relationships with others] was composed of the subcategories of 〈Growing up with a lot of people around $\rangle$ etc. in childhood, 〈Connection with friends) etc. in adolescence, 〈Raising my family) etc. in adulthood, and 〈Contributing to the community) etc. in maturity. The common subcategory composing [Cultivated capability to endure] between the stages of childhood and maturity was 〈Continuing forbearance〉, the common subcategory composing the same in the stages of childhood and adolescence was 〈Life of poverty), and that in the stages of adolescence and adulthood was $\langle$ Experience of setbacks $\rangle$. The subcategories composing [Self-confidence regarding my own efforts] were 〈Efforts based on hardship〉 etc. in adolescence and $\langle\mathrm{My}$ efforts bore fruit $\rangle$ in adulthood and maturity. The subcategories composing [Satisfaction] were $\langle$ Enjoying my life〉 and 〈Hopes for my future etc. (Table 11).

In relation to the subjects' reflections on their lives, the following four categories were extracted : [Trust relationships with others], [Self-confidence regarding my own efforts], [Wanting to contribute to society], and [Let things be as they are]. The subcategories composing [Trust relationships with others] were 〈Gratitude to those around me $\rangle$ and 〈Respect for others〉. The subcategories composing [Self-confidence regarding my own efforts] were $\langle$ No regrets〉 and $\langle$ Satisfied with my own past $\rangle$. As new categories, [Wanting to contribute to society] and [Let things be as they are] were extracted. The subcategories constituting [Wanting to contribute to society] were (Passing things on to the next gen-

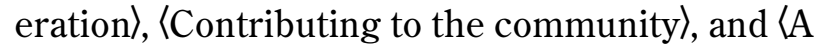
sense of danger concerning the current society). The subcategories making up [Let things be as they are] were 〈Things will work themselves out and 〈Accepting everything as it is〉 (Table 12).

In relation to the subjects' acceptance of and coping with difficulties in life, the following three categories were extracted: [Trust relationships with others], [Cultivated capability to endure], and [Selfconfidence regarding my own efforts]. The subcategories composing [Trust relationships with others]
Table 11. Categories of understanding of life during the period between childhood and maturity

\begin{tabular}{|c|c|}
\hline Subcategory & Category \\
\hline \multicolumn{2}{|c|}{ Childhood (preschool, school-age) } \\
\hline Long-lasting friendship & \multirow{2}{*}{$\begin{array}{l}\text { Trust relationships with peo- } \\
\text { ple around }\end{array}$} \\
\hline $\begin{array}{l}\text { Growing up with a lot of people } \\
\text { around }\end{array}$ & \\
\hline Family & \multirow{3}{*}{$\begin{array}{l}\text { Fond memories with people } \\
\text { around }\end{array}$} \\
\hline People around & \\
\hline Friends & \\
\hline Life of poverty & \multirow{2}{*}{ Cultivated capability to endure } \\
\hline Continuing forbearance & \\
\hline $\begin{array}{l}\text { Death and diseases of family } \\
\text { members }\end{array}$ & \multirow{4}{*}{$\begin{array}{l}\text { Unforgettable events hap- } \\
\text { pened in war time }\end{array}$} \\
\hline $\begin{array}{l}\text { The scene in which people were } \\
\text { not treated as human beings }\end{array}$ & \\
\hline Terror of war & \\
\hline Stolen joy & \\
\hline \multicolumn{2}{|c|}{ Adolescence } \\
\hline $\begin{array}{l}\text { Connection with family mem- } \\
\text { bers }\end{array}$ & \multirow[t]{2}{*}{$\begin{array}{l}\text { Trust relationships with peo- } \\
\text { ple around }\end{array}$} \\
\hline Connection with friends & \\
\hline Life of poverty & \multirow{3}{*}{ Cultivated capability to endure } \\
\hline Continuing forbearance & \\
\hline Experience of setbacks & \\
\hline Efforts based on hardship & \multirow{3}{*}{$\begin{array}{l}\text { Self-confidence regarding my } \\
\text { own efforts }\end{array}$} \\
\hline Wish for becoming independent & \\
\hline Stubbornness & \\
\hline \multicolumn{2}{|c|}{ Adulthood } \\
\hline Raising my family & \multirow{3}{*}{$\begin{array}{l}\text { Trust relationships with peo- } \\
\text { ple around }\end{array}$} \\
\hline Devoted to my family & \\
\hline Connection with people around & \\
\hline Continuing forbearance & \multirow{2}{*}{ Cultivated capability to endure } \\
\hline Experience of setbacks & \\
\hline My efforts bore fruit & \multirow{4}{*}{$\begin{array}{l}\text { Self-confidence regarding my } \\
\text { own efforts }\end{array}$} \\
\hline $\begin{array}{l}\text { Joy after going through endur- } \\
\text { ance }\end{array}$ & \\
\hline Realization of my own growth & \\
\hline Wish for becoming independent & \\
\hline \multicolumn{2}{|c|}{ Maturity } \\
\hline Devoted to my family & \multirow{5}{*}{$\begin{array}{l}\text { Trust relationships with peo- } \\
\text { ple around }\end{array}$} \\
\hline $\begin{array}{l}\text { Raising my family and the next } \\
\text { generation }\end{array}$ & \\
\hline Contributing to the community & \\
\hline Feeling of gratitude & \\
\hline Connection with people around & \\
\hline Continuing forbearance & Cultivated capability to endure \\
\hline My efforts bore fruit & \multirow{2}{*}{$\begin{array}{l}\text { Self-confidence regarding my } \\
\text { own efforts }\end{array}$} \\
\hline Stubbornness & \\
\hline Joy of working & \multirow{4}{*}{ Satisfaction } \\
\hline Enjoying my life & \\
\hline Changes in life & \\
\hline Hopes for my future & \\
\hline
\end{tabular}


Table 12. Reflections on past life

\begin{tabular}{|c|c|c|}
\hline Codes & Subcategories & Categories \\
\hline I got others involved in, and with their support, I was elected. (A) & \multirow{2}{*}{$\begin{array}{l}\text { Gratefulness to people } \\
\text { around }\end{array}$} & \multirow{4}{*}{$\begin{array}{l}\text { Trust relationships with } \\
\text { people around }\end{array}$} \\
\hline I was lucky to have met good people and friends from childhood. (G) & & \\
\hline I don't speak ill of others, I rather want to praise them. (C) & \multirow{2}{*}{ Respect for others } & \\
\hline I don't balance my profits and losses. $(\mathrm{H})$ & & \\
\hline $\begin{array}{l}\text { My life has been full of ups and downs. I don't look back. I have never regretted } \\
\text { anything in my life. (A) }\end{array}$ & \multirow{3}{*}{ I do not regret } & \multirow{6}{*}{$\begin{array}{l}\text { Self-confidence regard- } \\
\text { ing my own efforts }\end{array}$} \\
\hline $\begin{array}{l}\text { I don't look back much. There may still be some things that I can do in the } \\
\text { future. (B) }\end{array}$ & & \\
\hline $\begin{array}{l}\text { I worked a lot but also played a lot. I don't have any regret in my life. I try my } \\
\text { best within my capability. (H) }\end{array}$ & & \\
\hline $\begin{array}{l}\text { Although my life is not full of good days, it has been a good life. I am happy with } \\
\text { it. (C) }\end{array}$ & \multirow{3}{*}{$\begin{array}{l}\text { Satisfied with my own } \\
\text { past }\end{array}$} & \\
\hline I like to grow old as I am now. (F) & & \\
\hline $\begin{array}{l}\text { I was given opportunities to try a whole lot of things, rather than like I could } \\
\text { not do this or that. }(G)\end{array}$ & & \\
\hline $\begin{array}{l}\text { I would like to take care of those young people who have been through hardship } \\
\text { similar to mine, specially those without parents. I want them to have an ambition } \\
\text { for becoming a leader. (A) }\end{array}$ & \multirow{6}{*}{$\begin{array}{l}\text { Handing on to the next } \\
\text { generation }\end{array}$} & \multirow{14}{*}{$\begin{array}{l}\text { Wanting to contribute to } \\
\text { the society }\end{array}$} \\
\hline $\begin{array}{l}\text { I were to be reborn, I would like to engage in business activities in which I could } \\
\text { give young people opportunities to seriously think about Japan. (D) }\end{array}$ & & \\
\hline I feel that new possibilities have started to come up among young people. (G) & & \\
\hline $\begin{array}{l}\text { I have told my grandchildren that their health is all I want from them. The most } \\
\text { fortunate thing is that children and family members work diligently. Do not ask } \\
\text { for what you don't have. (H) }\end{array}$ & & \\
\hline $\begin{array}{l}\text { Women today do not take housework seriously. I want them to give consideration } \\
\text { to the roles and manners of traditional Japanese women. (E) }\end{array}$ & & \\
\hline $\begin{array}{l}\text { In my time, I felt oppressed and restricted by the era and could not find what I } \\
\text { was. Young people can live a life they choose. (G) }\end{array}$ & & \\
\hline I would like to do things which are helpful to others. (D) & \multirow{2}{*}{$\begin{array}{l}\text { Contributing to the com- } \\
\text { munity }\end{array}$} & \\
\hline $\begin{array}{l}\text { I want to be a person who can act for someone else. I want to do things through } \\
\text { which I can make others happy. }(\mathrm{H})\end{array}$ & & \\
\hline $\begin{array}{l}\text { Not all new things are good. There are good, old things. I want young people to } \\
\text { listen to us. (B) }\end{array}$ & \multirow{6}{*}{$\begin{array}{l}\text { Sense of danger concern- } \\
\text { ing the current society }\end{array}$} & \\
\hline Young mothers do not scold their children. (C) & & \\
\hline $\begin{array}{l}\text { As young people today don't challenge, they don't get hurt. I want them to be } \\
\text { hungry for success and independent. }(G)\end{array}$ & & \\
\hline $\begin{array}{l}\text { People have become foolish as there are too many luxuries around them. What } \\
\text { they lack is affection. Home education is important. }(\mathrm{H})\end{array}$ & & \\
\hline $\begin{array}{l}\text { Consideration and bonds have become weaker. Everyone takes it for granted that } \\
\text { people do things for others. }(\mathrm{H})\end{array}$ & & \\
\hline $\begin{array}{l}\text { The number of non-regular employees has exceeded } 20 \text { million. I wonder if that } \\
\text { kind of environment enables young people to have a dream. I think that such } \\
\text { an environment is a cause for a troubled society. (I) }\end{array}$ & & \\
\hline $\begin{array}{l}\text { I was a single mother and raised my child by myself. Things worked themselves } \\
\text { out. I let things be whatever they were to be. As everyone had a hard time, I did } \\
\text { not think I was in a difficult situation. (F) }\end{array}$ & \multirow[t]{2}{*}{$\begin{array}{l}\text { Things work themselves } \\
\text { out }\end{array}$} & \multirow{7}{*}{ Let things be as they are } \\
\hline As my eldest son lives far, my wife and I have to support each other. (J) & & \\
\hline $\begin{array}{l}\text { We all experience hardship regardless of in war time or while at work. After we } \\
\text { have been through such hardship and forgotten it somehow. (A) }\end{array}$ & \multirow{5}{*}{$\begin{array}{l}\text { Accepting everything as } \\
\text { it is }\end{array}$} & \\
\hline $\begin{array}{l}\text { I would want to change nothing in my life even if I were to be reborn. I am happy } \\
\text { with my life as it is. (C) }\end{array}$ & & \\
\hline $\begin{array}{l}\text { Things did not always work out well for me, but it was because my learning and } \\
\text { efforts were not sufficient. (D) }\end{array}$ & & \\
\hline $\begin{array}{l}\text { We need to know what we are in order to bloom, and we should not envy others. } \\
\text { We don't have to be like others. (G) }\end{array}$ & & \\
\hline I am proud of my own life. $(\mathrm{H})$ & & \\
\hline
\end{tabular}


were $\langle$ Respect for senior citizens $\rangle$ and $\langle$ Support from people around mel. [Cultivated capability to endure] was composed of the subcategories of $\langle A c-$ cepting forbearance〉 and 〈Satisfied with what is in my hand $\rangle$. [Self-confidence regarding my own efforts] was composed of the subcategories of 〈Living positively〉, 〈Having faith〉, 〈Believing in my own capability〉, and 〈Utilizing experiences from my childhood (Table 13).

In relation to the subjects' acceptance of their own death, the following three categories were extracted: [Acceptance of my own death], [Concern for those left behind], and [Fear of death]. The six subcategories of 〈Living a full life〉, 〈Hoping for a sudden death〉, 〈Preparation for death〉, 〈Life as a bonus〉, 〈Afterworld〉, and 〈Viewing death objectively $\rangle$ constituted [Acceptance of my own death]. The subcategories of $\langle$ Concern for children $\rangle$ and $\langle$ Concern for others $\rangle$ composed [Concern for those left behind]. The three subcategories of 〈Attitude showing that I do not think about death〉, 〈Scared of the process toward death $\rangle$, and $\langle$ Financial concern $\rangle$ constituted [Fear of death] (Table 14).

The relationships among the categories are illustrated in Figure 1. The categories of the subjects' understanding of life during the stages from childhood to maturity, their reflections on life, and their acceptance of difficulty and death were illustrated graphically in accordance with EPSI.

Table 13. Acceptance of and coping with difficulties in life

\begin{tabular}{|c|c|c|}
\hline Codes & Subcategories & Categories \\
\hline $\begin{array}{l}\text { If young people listen to and do what senior citizens, say, they will not go wrong. } \\
\text { (A) }\end{array}$ & \multirow{2}{*}{$\begin{array}{l}\text { Respect for senior citi- } \\
\text { zens }\end{array}$} & \multirow{4}{*}{$\begin{array}{l}\text { Trust relationships with } \\
\text { people around }\end{array}$} \\
\hline $\begin{array}{l}\text { When I was about to get married, my mother told me to exercise patience, } \\
\text { saying, "Flowers bloom at the place where patience is." (B) }\end{array}$ & & \\
\hline Money is not a problem. The people in my neighborhood were kind to me. (C) & \multirow[b]{2}{*}{$\begin{array}{l}\text { Support from people a- } \\
\text { round }\end{array}$} & \\
\hline $\begin{array}{l}\text { For various reasons, I built my house three times in three years. My parents } \\
\text { paid some of the cost for me from their retirement allowance. }(\mathrm{H})\end{array}$ & & \\
\hline Whatever problem I face, I choose to think, "All I need is patience." (B) & \multirow{2}{*}{ Accepting forbearance } & \multirow{4}{*}{$\begin{array}{l}\text { Cultivated capability to } \\
\text { endure }\end{array}$} \\
\hline I don't worry about things, I just stay quite indifferent. $(\mathrm{H})$ & & \\
\hline I tell myself that what I am now is at my best. (C) & \multirow{2}{*}{$\begin{array}{l}\text { Satisfied with what is in } \\
\text { my hand }\end{array}$} & \\
\hline I keep my expectations realistic. (I) & & \\
\hline My thoughts and attitude are all positive, I don't look back. (A) & \multirow{5}{*}{ Living positively } & \multirow{17}{*}{$\begin{array}{l}\text { Self-confidence regard- } \\
\text { ing my own efforts }\end{array}$} \\
\hline $\begin{array}{l}\text { I keep thinking that everything works out alright and good things happen as } \\
\text { long as I am alive. (C) }\end{array}$ & & \\
\hline Reading books on self-development enables me to think positively. (E) & & \\
\hline Unless I look ahead and make efforts, I cannot reach happiness. (H) & & \\
\hline I keep my motivation for working even on small things. (I) & & \\
\hline You have got to have a faith. (A) & \multirow{7}{*}{ Having a faith } & \\
\hline Nothing you think is impossible to do. (B) & & \\
\hline I was supported by invisible power. (C) & & \\
\hline Things work themselves out as time passes. (F) & & \\
\hline $\begin{array}{l}\text { I take responsibility for things I have started within my capability until I complete } \\
\text { them. (G) }\end{array}$ & & \\
\hline $\begin{array}{l}\text { Unless you have overcome your own difficulties, people don't offer their support. } \\
(\mathrm{H})\end{array}$ & & \\
\hline If you do your best as occasions arise, you can make progress. (I) & & \\
\hline I have dealt with problems by myself. I don't reply on others. (B) (F) (G) & \multirow{2}{*}{$\begin{array}{l}\text { Believing my own capa- } \\
\text { bility }\end{array}$} & \\
\hline $\begin{array}{l}\text { Unless you have overcome your own difficulties, people don't offer their support. } \\
(\mathrm{H})\end{array}$ & & \\
\hline $\begin{array}{l}\text { When you are in a difficult time, that is the time you should be kind to others. } \\
\text { (H) }\end{array}$ & \multirow{3}{*}{$\begin{array}{l}\text { Utilizing experiences } \\
\text { from childhood }\end{array}$} & \\
\hline The hardship I experienced during childhood has become my foundation. $(\mathrm{H})$ & & \\
\hline $\begin{array}{l}\text { Food was scarcely available after the war. Although it was a hard time, I looked } \\
\text { back on it and made efforts in various ways. (J) }\end{array}$ & & \\
\hline
\end{tabular}


Table 14. Ways to accept my own death

\begin{tabular}{|c|c|c|}
\hline Codes & Subcategories & Categories \\
\hline I am not afraid of dying as I have done what I wanted to do. (A) & \multirow{3}{*}{ Living a full life } & \multirow{12}{*}{$\begin{array}{l}\text { Acceptance of my own } \\
\text { death }\end{array}$} \\
\hline $\begin{array}{l}\text { When I cannot make a contribution to others any longer, I would like to pass } \\
\text { away without life-extension treatment. (D) }\end{array}$ & & \\
\hline I have no regret about my life. $(\mathrm{H})$ & & \\
\hline $\begin{array}{l}\text { I want to spend my time healthily until the day of my death and to pass away in } \\
\text { good spirits. (A) }\end{array}$ & \multirow{3}{*}{$\begin{array}{l}\text { Hoping for a sudden } \\
\text { death }\end{array}$} & \\
\hline I want to pass away abruptly. (C) & & \\
\hline I have made efforts to be able to walk well until my last moment. $(\mathrm{H})$ & & \\
\hline I am mentally prepared. (F) & Preparation for death & \\
\hline For me, it is like I died once. My current life is just like a bonus. (D) & \multirow[b]{2}{*}{ Life as a bonus } & \\
\hline $\begin{array}{l}\text { I thought I was going to die at around the age of 30, but I have lived more than } \\
\text { twice as much as that. That is why I can go anytime. (E) }\end{array}$ & & \\
\hline I don't see death is the end. (E) & Afterworld & \\
\hline I wonder that if I do my best as occasions arise, I would reach my end. (I) & \multirow{2}{*}{$\begin{array}{l}\text { Viewing death objec- } \\
\text { tively }\end{array}$} & \\
\hline $\begin{array}{l}\text { There is too big a gap between the healthy life expectancy and the average life } \\
\text { expectancy (of senior people today). (G) }\end{array}$ & & \\
\hline $\begin{array}{l}\text { I don't want to cause a problem for my child. However, when I get old, I guess } \\
\text { it is inevitable that I have to spend much time in bed. I want to pass away in } \\
\text { three months. (B) }\end{array}$ & \multirow{3}{*}{ Concern for children } & \multirow{5}{*}{$\begin{array}{l}\text { Concern for those left } \\
\text { behind }\end{array}$} \\
\hline $\begin{array}{l}\text { My husband passed away three days after having a disease. He did not cause } \\
\text { trouble to our child. I would like to go in the same manner. (H) }\end{array}$ & & \\
\hline $\begin{array}{l}\text { I just want to make sure that I don't cause trouble to my child who will be left } \\
\text { behind alone. (J) }\end{array}$ & & \\
\hline Becoming bedridden will cause trouble to everyone. (C) & \multirow[b]{2}{*}{ Concern for others } & \\
\hline $\begin{array}{l}\text { I want to pass away with a smile on my face showing that I have lived a full life. } \\
\text { I want to die with a face showing my satisfaction with my life. (G) }\end{array}$ & & \\
\hline I don't think much (about death). (F) & \multirow{2}{*}{$\begin{array}{l}\text { Attitude showing that I } \\
\text { do not think about death }\end{array}$} & \multirow{5}{*}{ Fear of death } \\
\hline Difficult (to think about the last that I want). (I) & & \\
\hline I am scared. I wonder what it turns out to be. (C) & \multirow{2}{*}{$\begin{array}{l}\text { Scared of the process to- } \\
\text { ward death }\end{array}$} & \\
\hline I don't want to suffer from diseases. (B) (E) (J) & & \\
\hline $\begin{array}{l}\text { It is a problem for me if I suffer from a disease and consequently need a large } \\
\text { sum of money. }(\mathrm{J})\end{array}$ & Financial concern & \\
\hline
\end{tabular}

\section{DISCUSSION}

\section{Questionnaire survey}

Although $58 \%$ of the questionnaire subjects stated that they had chronic diseases, $80 \%$ of the subjects' subjective views on health were good to some extent. This means that they were relatively healthy senior citizens.

With regard to the alpha coefficients of the DAP$\mathrm{R}$ sub-factors and the EPSI sub-factors, although the alpha coefficient of "Generativity" of the EPSI was a little low, at 0.59 , the other seven factors obtained satisfactory reliability. In particular, high reliability of the DAP-R sub-factors was confirmed. Accordingly, we consider that these scales are effective for examining Erikson's Psychosocial Stages and attitudes toward death.

The female subjects scored significantly higher in "Trust", "Autonomy", and "Intimacy" of the EPSI than the male subjects. Women may be able to trust themselves and others and to decide things more freely than men. Accordingly, women are expected to be able to maintain trust relationships with others while having close relationships, and less frequently feel lonely, as they can develop good relationships with people around them. Subjects aged 75 or older scored significantly higher in "Industry" and "Generativity" than those aged between 60 and 74 years. This suggests that as people age, they acquire more self-efficacy in using their skills and become more interested in raising the next generation.

The reason that the subjects with a high accomplishment level of "Ego-Integrity" of the EPSI showed high scores in the other EPSI sub-factors was considered to be that they had accomplished developmental tasks up until the stage of maturity. On the other hand, the high EPSI "Integrity" group scored significantly lower in "Fear of death", "Avoidance of death", and "Escape acceptance" than the low integrity group. From this, we considered that 
the subjects' acceptance of their own lives so far eased their fear of death and prepared them to face death. This is supported by the fact that as the level of EPSI "Integrity" increased, subjects' fear of death tended to subside and they tended not to avoid thinking about death. This finding agrees with that of a preceding study (8). "Fear of death" was also considered to be negatively influenced by "Initiative". We consider that the fear of death is not great for people who embark on things on their own initiative and are prepared to take responsibility for their own actions. Their attitude to face their own death without escaping from it is considered to form one of the factors constituting their fearless attitude toward death.

Regarding effects of the sub-items of the EPSI "Integrity" on the DAP-R sub-factors, it is suggested that the "Fear of death" grows when a person cannot "accept his/her own life" and each time this person thinks that "there are other ways s/he can live his/her life" and "his/her life is full of failures". As a result of these quantitative analyses, we have clarified that the fear of death subsides when people accept their lives so far and are fully convinced that there is nothing wrong with their lives despite failures they may have experienced.

\section{Interview survey}

Although 4 out of 10 interview subjects answered that they had chronic diseases, 9 subjects' subjective views on health were good to some extent. From this, it was seen that they were relatively healthy senior citizens. Further, the average EPSI score of the interview subjects was 203 points. This score greatly exceeded the average score of the questionnaire subjects (186 points). This suggests that they were senior citizens with high levels of Ego-Integrity accomplishment.

Physical and psychological functions of individuals during the stage of maturity differ greatly according to age ; such differences widen with age. Further, such individuals' social roles differ depending on their environment. It is necessary to collect the meanings of the words people speak. Combining several methods may improve the collected data and enable us to get a clearer picture of the phenomenon we seek to clarify (24). Quantitative research might allow clarification of the tendencies and characteristics of subject groups, but not individual subjects' experiences in the background.

In the contents of the narratives from the interview subjects, there were many expressions of integrity, such as "My life has been full of ups and downs, but I have never regretted anything" (A), "Although my life is not full of good days, it has been a good life" (C), and "Although my disease has not been cured, all I can do is to live positively" (E). In the process of qualitatively analyzing these narratives, we specifically grasped how integrity had taken place. For instance, the subjects' (Life of poverty) formed their capability to endure, which in turn became a driving force for living their lives. Another example was that the motivation of "I live for those who died in war and of disease" became one of the [Unforgettable events that happened during wartime], and this was considered to have become a foundational experience leading to the subjects' sense of value.

[Trust relationships with others] and [Cultivated capability to endure] were the extracted categories common to each of the stages from childhood to maturity, and were considered to have influenced the subjects' integrity throughout their entire lives. [Self-confidence regarding my own efforts] first emerged in the stage of adolescence and was present in all the subsequent stages of life. These three categories were extracted from narratives on the acceptance of and coping with difficulties in life. [Trust relationships with others] and [Cultivated capability to endure], which were mentioned throughout the subjects' lives, and [Self-confidence regarding my own efforts], which was mentioned in the developmental stages other than childhood, were considered to represent the linchpin of subjects' thinking and their ways of coping with difficulties in their lives.

Various images emerged from the categories of [Trust relationships with others], [Cultivated capability to endure], and [Self-confidence regarding my own efforts] (in relation to Figure 1). Through experiencing [Fond memories with others] and [Unforgettable events that happened during wartime] in the childhood stage, the subjects were considered to have formed [Trust relationships with others]. On the basis of such relationships, they presumably acquired the [Cultivated capability to endure]. Furthermore, they were considered to have developed [Self-confidence regarding my own efforts] on the basis of their trust relationships and capability of endurance after the stage of adolescence. We considered that they did not accomplish the developmental tasks in a linear fashion. They made 〈Efforts based on hardship〉 while going through 〈Experience of setbacks〉 and 〈Continuing forbearance〉, 
and went back and forth until they reached their current state of being [Satisfied with the current situation] in the stage of maturity. Further, [Trust relationships with others], [Cultivated capability to endure], and [Self-confidence regarding my own efforts], which were the main categories to grasp life between childhood to maturity, overlapped with the categories for the acceptance of difficulties. From this, we inferred that their thoughts behind these three categories led to their ways of coping with difficulties in life.

We considered that the subjects acquired what Erikson $(2,3)$ called trust in the environment where they grew up among their families, friends, and other people in their childhood. They accomplished the developmental tasks of autonomy and initiative in this stage $(2,3)$ through learning from people around them and from relationships with such people. Furthermore, we considered that their forbearance cultivated through their experience of war and life of poverty led them to acquire Industry $(2,3)$. They managed to establish their "Ego-Identity" by having [Self-confidence regarding my own efforts], which had been developed through 〈Efforts based on hardship $\rangle$ and 〈Experience of setbacks〉 and through overcoming such hardships with 〈Stubbornness〉. 〈Wish for becoming independent । and $\langle$ Realization of my own growth $\rangle$ were considered to have helped the subjects acquire intimacy. The subjects arrived at the category of [Wanting to contribute to society] as they grew old and reflected on their lives, and this category presumably expressed their wishes for contributing to society, such as 〈Passing things on to the next generation〉 and 〈Contributing to the community〉. This was considered to have led them to acquire "Generativity". Further, the category of [Let things be as they are] was expressed as their attitude that they allowed and accepted everything as it was after going through various experiences. This was considered to be the very category indicating "Integrity", the developmental task in the maturity stage formulated by Erikson $(2,3)$.

On the basis of these findings, the subjects went through [Acceptance of my own death] despite their [Fear of death], and became prepared to face their death while having a [Concern for those left behind]. We inferred that integrity led them to accept their own lives and formed their mentality to accept death without avoiding it.

\section{Study Limitations and Issues Ahead}

As the subjects of this research were elderly students, they were expected to be more intellectually curious and active than other senior citizens. Despite the potential of bias in the subjects, it was possible to clarify the attitudes toward death of elderly persons who had a high level of Ego-Identity accomplishment. In the future, it will be necessary to examine different types of senior citizens and accumulate a variety of evidence. Furthermore, it will be necessary to examine intervention methods for supporting the elderly in their acceptance of death from the perspective of lifelong development.

\section{CONCLUSION}

In the present study, we conducted a questionnaire survey and interviewed subjects who were willing to participate in an interview. From this, we examined the relationship between the developmental stages of senior citizens and their attitudes toward death. Emphasizing the understanding of the subjects from the aspects of both numerical data and the study subjects' narratives, and focusing on multiple aspects of the meaning of the data, we combined different data-collection methods and procedures. We believe that employing this method enabled us to deepen our understanding of the manysided meanings of elderly people's identities and attitudes toward death.

From our quantitative and qualitative research, we have established that the accomplishment of "Integrity", which is the developmental task in the maturity stage, leads to the attitude of accepting one's whole life as defined above. Further, we have clarified that "Integrity" promotes the acceptance of death lying ahead without turning away from it.

Therefore, for relatively healthy senior citizens living in a community, identity development stages are related to attitudes toward their own death.

\section{CONFLICT OF INTEREST}

None of the authors have any conflicts of interest to declare. 


\section{ACKNOWLEDGMENTS}

The authors extend their sincere thanks to the participants who cooperated in this study. Additionally, we would like to thank Professor Tadashi Kondo and Professor Mari Haku for their helpful advice. Lastly, we would like to thank Dean Fusako Esaki of the Faculty of Nursing at Shikoku University for her significant interest in our study.

\section{REFERENCES}

1. Cabinet Office Heisei 24-year version Aging Society white paper 2012 : http : //www8.cao.go. jp/kourei/whitepaper/index-w.html (Access date : 2013/08/10)

2. Erikson EH : Childhood and Society. W. W. Norton \& Co., New York, 1950, pp.241-274

3. Erikson EH : Identity and the life cycle. International University Press, New York, 1959, pp.100-107

4. Nakagi S: The effecting factors to the attitude toward the death of the elderly. Japanese Journal of Clinical Thanatology 16 (1) : 67-78, 2011 (in Japanese)

5. Neimeyer RA, Van BD : Dying : Facing the facts. In : Neimeyer RA, eds. Death Anxiety. Taylor \& Francis, Philadelphia, 1995

6. Feifel $\mathrm{H}$ : The meaning of death. McGraw-Hill, New York, 1959

7. Swenson WM : Attitudes towards death in an aged population. Journal of Gerontology 16 : 49-52, 1961

8. Kishimoto $\mathrm{H}$ : Mind staring at death -Ten years fought against cancer- Kodansha, Tokyo, 1973 (in Japanese)

9. Kawai H, Yanagita K: To the depths of the heart -to escape social depression-. Shincho -Bunko, Tokyo, 2003, pp.47-55 (in Japanese)

10. Kouno $\mathrm{H}$ : Illness and self realization. Sogensha, Osaka, 1984, pp.109-125 (in Japanese)

11. Newman BM, Newman PR:Development through life : A psychosocial approach. 5rd ed. Dorsey Press, California, 1991, pp.40-54

12. Levinson DJ:The season of man's life. Ballantine Books, New York, 1978, pp.33-39
13. Nakanishi N, Sakata A : EPSI-Erikson psychosocial stage Inventory. In : Kamisato I, ed. Psychological assessment handbook 2nd edition. Nishimurashoten, Tokyo, 2008, pp.365-376 (in Japanese)

14. Rosenthal DA, Gurney RM, Moore SM : From trust to intimacy. New inventory for examining Erikson's stage of psychosocial development. J Youth Adoles 10 : 525-537, 1981

15. Wong PTP, Reker GT, Gesser G : The death attitude profile-revised : Multidimensional measure of attitude towards death. In : Neimeyer RA, ed. Death anxiety handbook : Research, instrumentation, and application. Taylor \& Francis, Washington, DC, 1995, pp.121-148

16. Kumabe T : Psychological study of Japanese attitudes of life and death -4 factors influencing attitudes to death-. Health Psychology Research 19 (1) : 10-24, 2006 (in Japanese)

17. Haight BK, Coleman $\mathrm{P}$, Lord $\mathrm{K}$ : The linchpins of a successful life review : Structure, evaluation, and individuality. In : Haight BK, Webster JD, eds. The art and science of reminiscing : Theory, research, methods, and applications. Taylor \& Francis, Oxford, 1995, pp.179-192

18. Nomura $\mathrm{N}$ : Study on effects of self-esteem of elderly local residents' personal reminiscence. Psychology Research 80 : 42-47, 2009 (in Japanese)

19. Ueta $\mathrm{R}$ : Human development science through life. Miwasyoten, Tokyo, 1996 (in Japanese)

20. Moriya K : A psychological research of ego development in old age. Kazamasyobou, Tokyo, 1993 (in Japanese)

21. Burnside I, Haight B : Reminiscence and life review : therapeutic interventions for older people. Nurse Pract 19 (4) : 55-61, 1994

22. Erikson EH : The life cycle completed. W. W. Norton \& Co., New York, 1982, pp.55-82

23. Erikson $\mathrm{EH}$ : Vital involvement in old age. W. W. Norton \& Co., New York, 1986, pp.32-53

24. Tutui M, Ota Y, Watanabe K, Emoto R, Kai K, Sekine H, Nakamura A : Changes of research method in Japan -quantitative research, qualitative research and triangulation-. Int Nurs Rev 28 (2) : 37-46, 2005 (in Japanese) 